\title{
Study on the Training Mode of Innovative and Entrepreneurial Talents Regarding Business Administration Management in the Context of Internet plus Era
}

\author{
Yanfa Chen \\ NanChang Institute of Science \& Technology, Nanchang, 330108
}

Keywords: Business Administration; Innovation and Entrepreneurship; Talents Training

\begin{abstract}
With the approaching of internet plus era, it is urgent for Business Management to explore a new mode of innovation and entrepreneurship. By analyzing the current condition of business administration, we can find out that there is a glittering array of problems, including shortage of innovation and entrepreneurship consciousness, out-of-date teaching philosophies, insufficient basic resources, lame security system, inaccurate targets, incomplete course setting system and improper teaching methods etc. The good point is, improvement methods have been suggested to construct a professional innovation and entrepreneurship training mode after clearing the opportunities and challenges that might be brought along with the internet.
\end{abstract}

\section{Introduction}

The deepening and development of Internet technology has brought great changes to the social life of the public, so that the communication between people is more and more convenient while the information dissemination is very quick. The concept of Internet plus was firstly suggested by Premier Li Keqiang in government report. Since then, it became a hot topic while soaring enterprises firmly adhere to this concept and help to promote the transformation and development of certain amount of industries by adopting the latest technology. The main function of internet plus is to obtain the optimal allocation by taking advantage of the internet. What's more, the real economy will be enhanced and innovated by integrating the latest results of internet. Hence, a new economic development status will emerge based on internet. The emergence of internet plus has affected various fields and more and more industries including agriculture, education and transportation are connected to internet plus. Thus, a new economic formation has been created based on internet + agriculture and internet + education. Business administration is a subject, aiming to study on the basic theories and methods of economic management in commercial enterprises and its development is closely related to the economic growth. So, how to introduce innovation and entrepreneurship into higher education reform is a problem which needs high attention and deep thoughts.

\section{Connotation and Characteristics of Innovative and Entrepreneurial Talents}

Innovation, generally speaking, is to abandon the old and create something new; entrepreneurship is to create an industry and entrepreneurs should be equipped with innovation consciousness as well as abilities to take the initiative to practice by fully and comprehensively utilizing their knowledge. By combining strict science knowledge and pioneer spirit, people can find and seize opportunities in the fierce competition environment. Furthermore, people are able to create new products or service by trying unremitting efforts to create wealth, realize individual value and contribute to making the society progress.

The entrepreneurship projects for current college students are predominantly focused on service industries, especially commerce, circulation, logistics (occupying 54.31\%). Based on that, we can see those entrepreneurship fields belong to the business administration, which is closely related to college students. Therefore, it is easier to start. Meanwhile, students studying commerce are practical and have an active mind, better adaptability, passion and adventure spirit. Therefore, it is easier for those students to start up a business. Judging from the perspective of business 
administration, those students were exposed to lots of business knowledge and they are better partners to cooperate with. In addition, they have the capability to use knowledge in real life to embrace challenges looming ahead and seize opportunities to contribute to the society-and become entrepreneurs.

\section{Existing Problems of the Current Business Administration Training Mode}

Our country needs more all-around talents with the development of economy. Business administration should integrate with entrepreneurship education, break the traditional teaching model centered on teachers, teaching materials and classrooms, and strengthen students' entrepreneurial and innovative ability so as to help them be engaged with creative and entrepreneur work. However, the current business administration management entrepreneurship education is still in the initial stage with a short development time. What's more, along with the special situation of China, students are exposed to theories often rather than practice. Furthermore, there are a glittering array of drawbacks if we still adopt the previous academic research training mode.

Firstly, Single Training Mode. Business administration does not have its characteristics and it has paid attention to theoretical teaching for such a long time. Meanwhile, the government has launched lots of policies to interrupt its free development and as a result the teaching mode is similar. Therefore, colleges can be deemed as the factory for standard cultivation, students do not have their special features and are unable to meet the diverse requirement of enterprises.

Poor Innovation and Entrepreneurship Education. Business administration management ignores the cultivation of innovative and entrepreneurial abilities and pays too much attention to theoretical teaching. For example, in the first three years, most of the courses are theoretical course, including public elementary courses as well as core courses. It is until the last year that students can have access to practice and practical courses. As a result, students are not cultivated well and they cannot provide useful knowledge to solve problems and meet the requirement of the society.

Imperfect Cooperation and Cultivation Mode. The entrepreneurship education in America has been mature and the collaboration among the government, enterprises and colleges can help to cultivate students' ability to be self-employed and start up a business. In America, colleges will set courses based on their features and the ability o students and at the same time help students to apply knowledge into reality. Entrepreneurship is a comprehensive and social education, which cannot only be created based on knowledge but also through the improvement of faculties, course setting and practice.

\section{The Innovative and Entrepreneurial Talents Training Mode For Business Administration Management Students in the Context of Internet Plus}

The internet plus era has brought about both challenges and opportunities for the innovative and entrepreneurship talents training for business administration management students. Therefore, while setting a training mode, we have to seize the opportunities and avoid threats. By combining the existing problems and the logic relation between problems while setting the innovative and entrepreneurial talents training mode, this paper is going to come up with a new cultivation mode from the following perspectives:

Cultivate Innovative and Entrepreneurial Consciousness, update Innovative and Entrepreneurial Teaching Philosophy. The lack of innovative and entrepreneurial awareness as well as some old teaching philosophies are the fundamental causes for affecting the education. Therefore, it is of pivotal importance to update the philosophy while cultivating the consciousness. The business administration management in colleges should pay more attention to cultivating innovative and entrepreneurship abilities rather than single knowledge imparting and strengthen their practical abilities.

Establish basic Resource Support for Cultivating Innovative and Entrepreneurial Abilities.The innovative and entrepreneurial ability cultivation needs a certain amount of basic resources. Therefore, the business administration management project also needs resources support 
and we have to greatly integrate practical resources and establish an entrepreneurship platform. Moreover, college students are the main stream of collaborative innovation so colleges should establish a platform to carry out deep cooperation between colleges and enterprises to encourage students to innovate and at the same time improve the quality and value. Furthermore, a cooperative platform of entrepreneurship project and funding support can also be established by government, venture capital firm so as to construct a science technology park for college students entrepreneurship.

Strengthen Security System. Colleges should set a series of innovative and entrepreneurial work schemes and introduce the schemes to the development. For example, colleges should formulate and perfect the suggestions, awards system, competition system etc to encourage students and teachers to participate in related activities and establish projects to help students create cases to refer to. Meanwhile, they should also give students support in terms of funds and encourage them to innovate and start up a business with a foundation program so as to guarantee the ability cultivation.

Clear Target Positioning.In the current era, the target of business administration management should be creating talents who can be adapted to the social development and cultivate interdisciplinary talents. We cannot only pay attention to theoretical results but also highlight practical ability cultivation. The main purpose of innovative and entrepreneurial education is to help them be aware of the concept. Students can master the basic theory, strengthen innovative spirit and learn economics, management, sociology, psychology, law, philosophy, literature, art, ethics knowledge etc to cultivate strategic planning ability, decision-making ability, execution ability, communication and coordination ability, team formation ability etc.

\section{Conclusion}

The business administration management for innovative and entrepreneurial education in China is still in its infancy and has a short development time. In addition, coupled with China's special conditions, the teaching mode is single and weak and the cooperation mechanism is imperfect. Therefore, we should strengthen the concept of entrepreneurship, change the concept of education, set up business management curriculum system, establish cooperative system between government and enterprises, promote practical activities, create a positive entrepreneurial culture to guarantee its sound development.

\section{References}

[1].Ermakova N Y, Fokina O V, Tyufiakova E S, et al. Business Administration as a Basis for Development of Global Entrepreneurship[J]. European Research Studies Journal, 2016, xix.

[2]. Yi-Bo L, Shi X X, Wang S J. The Study of the Status and Development Direction of Business Administration Case Study in China: Based on Co-word Network Analysis[J]. Journal of Management Case Studies, 2015.

[3]. Chen S, Wang Z. Gray model system of talent scale of information resources management of large state-owned enterprise[C]// International Conference on Business Management and Electronic Information. IEEE, 2011:907-909.

[4].Ying-Shan L I. Constructing the "School-Enterprise Integration" Administration Management Specialty Curriculum System at Higher Vocational Colleges[J]. Journal of Hebei Tourism Vocational College, 2014.

[5].Hayat S A. Applying Enterprise Risk Management on a Fiber Board Manufacturing Industrial Case[J]. International Journal of Risk, Contingency Management, 2014, 3.

[6].Baporikar N. Knowledge Management in Small and Medium Enterprises[J]. Organizational Innovation , It Governance in Emerging Economies, 2015.

[7].Looy A V, Backer M D, Poels G. A conceptual framework and classification of capability areas for business process maturity[J]. Enterprise Information Systems, 2014, 8(2):188-224.

[8].Bibu N, Lisetchi M. Looking for a management model of the social enterprise. The case of Romania[J]. 2015. 
[9]. Tang X M, Min W U, Management S O. Corporate Social Responsibility Education in Business Administration Major[J]. World, Chongqing, 2014.

[10]. Kim A A, Sadatsafavi H, Soucek M K, et al. An Integrated Approach to Implementing Enterprise Resource Planning Systems for a Large Transportation Agency[J]. Contact Dermatitis, 2015, 57(3):195-196.

[11]. Young K, Pagliari S. Capital united? Business unity in regulatory politics and the special place of finance[J]. Regulation, Governance, 2017, 11(1):3-23.

[12]. Zheng X, Alver J. A Modification of Efficacy Coefficient Model for Enterprise Performance Evaluation[J]. Journal of Applied Management, Investments, 2015, 4. 